from 70 nests in 1967 to 178 nests in 1968 , and over 900 young were fledged this year. Yellow-shafted Flickers took up nesting activities in two houses and raised a total of 10 young, while one pair of Starlings nested and raised five young. House Sparrows used 116 houses for nest sites, most of them being the first ones that I made which are located around our farmyard. I was, at first, pleased to have them nesting because, at that time, I did not know how to attract Mountain Bluebirds and Tree Swallows. In spite of the large number of House Sparrows nesting around the farm, there are very few houses occupied by them in the surrounding fields. Another interesting fact is that the House Sparrow population does not appear to be increasing on our farm.

Vandals took their toll of 21 houses this year. Some were stolen while others were pulled down and left lying on the ground. A few were used as targets for shooting and some were just literally demolished. Stubble fires and cattle destroyed eight of them.

A total of 65 houses have been distributed to various people in Saskatchewan but I have not received reports from them.

After everything is accounted for and totalled up it leaves about 30 houses unoccupied during the 1968 breeding season. Therefore, it has been another successful year for my projects.

I plan on making another 100-150 houses this winter and putting them out in a northeasterly direction to link up with those being set up by the Yorkton Natural History Society thus completing a second bluebird trail.

\title{
AN ATTEMPT BY A RUFFED GROUSE TO EAT A MOUSE
}

by Robert W. Nero, Manitoba Museum of Man and Nature, 147 James Avenue, Winnipeg

A dead Ruffed Grouse (Bonasa umbellus) with the tail and hind quarters of a large mouse protruding from its gaping bill was found in mid-June, 1967 at Big Whiteshell Lake in eastern Manitoba by Allan G. Watts, Winnipeg. The latter delivered it to Ken Hawkins, a local taxidermist, who shortly thereafter invited us to make a brief examination of the frozen but still intact bird and mouse. The size and position of the mouse, which was lodged in the bird's throat, seemingly could have caused the death of the grouse through suffocation. Further examination recently became possible after the grouse, a healthylooking adult male, had been skinned in preparation for mounting.

Before attempting to eat the mouse the grouse had foraged on a variety of plants. A small handful of green leaf-tips from its gizzard was comprised of mainly wild strawberry
(Fragaria sp.), a bramble (Rubus sp.) and a currant (Ribes sp.). Hawkweed (Crepis?), alumroot (Heuchera richardsonii), and gill-over-the-ground or ground ivy (Glechoma hederaceae) were present, along with a number of unidentified species. Two pond snails (Stagnicola sp.) were also found in the gizzard.

The mouse was an adult male Deer Mouse (Peromyscus maniculatus) about four inches long, not including the tail. Judging by its condition the mouse must have been fresh when picked up by the grouse. Damage to its skull could have been caused by the grouse. It was thought that the mouse may have become caught in the throat membrane by a broken bone, but there was nothing to indicate this; evidently it was simply too bulky to swallow. This is supported by the fact that it was difficult to extract from the bird and that its ribs had 
been crushed, evidently by the pressure of the throat.

An extensive report on the Ruffed Grouse (Bump, Darrow, Edminster, and Crissey. 1947. The Ruffed Grouse, life history, propagation, management. New York State Conservation Dept., New York, 915 pp.) shows that this species eats a great variety of invertebrate animals, including snails (87 in one crop), and small clams and mussels. As expected, they seldom prey on vertebrates. They have, however, eaten reptiles, birds, and mammals. Records include a 17-inch green snake and a slightly smaller garter snake. Bones from a small unidenti- fied bird were found in one grouse and feather remains in another. The only reported mammalian food item, however, was based on the "even more mystifying" appearance of rabbit hairs in two other specimens. The above reference relates such peculiar prey species to "stress of circumstances." The present record is further evidence that Ruffed Grouse may occasionally attempt to take a small mammal, though this may not generally be feasible.

I am indebted to Dr. Jennifer $M$. Walker for the plant identifications. W. Harvey Beck identified the snail and the mouse.

\section{SLATE-COLORED JUNCO NESTING IN BARN SWALLOW NEST; BROWN-HEADED COWBIRD PARASITISM ON JUNCO AND BARN SWALLOW}

by David R. M. Hatch, Oak Lake, Manitoba

On June 19, 1968, I observed a pair of Slate-colored Juncos carrying food into an old Barn Swallow nest under the eave of the museum building in the town of Wasagaming in Riding Mountain National Park. Upon examination, the nest was found to contain a nestling Brown-headed Cowbird about six days old, but no young juncos. The nest, which was 13 feet above the ground, was lined with fine grasses and with an inner cup of horsehair. The old inner cup of the Barn Swallow nest was full of grass which could even be seen above the mud edge. Both adult juncos continued to feed the cowbird until June 22, at which time the young cowbird left the nest. I saw a junco on June 26 feeding a cowbird that could fly, and as they were only a little over 100 yards from the nest site assumed that they were the same birds. I have been unable to find a record of a junco nesting in similar circumstances.

Two of three active Barn Swallow nests found on June 19 under the eaves of the same building contained cowbird eggs. One nest held two cowbird eggs and one swallow egg; the other nest contained one cowbird egg and three swallow eggs. On June 24 all of the nests were knocked down by maintenance crews in preparation for sanding and varnishing the wooden building. Although we therefore lack information on the outcome of these particular clutches, it is clear that both pairs of swallows had accepted the foreign eggs and were incubating them during the period of observation. When one considers that there was a wide variation in the period in which the eggs were laid, two or more female cowbirds must have been involved. For example, both sets of eggs were still unhatched June 24, whereas the cowbird that hatched in the junco nest left the nest on its own accord by June 22 and was flying by June 26.

The Barn Swallow is listed by H. C. Friedmann (Host relations of parasitic cowbirds, 1963, U.S. Nat'l Mus. Bull. 233) as a "a very infrequent victim" and only five specific records 